\title{
Commuter Travel Pattern to OUSL Nawala: A Case Study
}

\author{
L. M. Prathapasinghe, D. B. Maddumaarachchi, \\ G. N. Damayanthi, and K. S. Weerasekera*
}

Department of Civil Engineering, The Open University of Sri Lanka, Sri Lanka

\section{Abstract}

This study intends to analyse the inflow pattern of commuters of OUSL Colombo Regional Center and Main University Nawala with their travel origins, and study their travel-mode patterns and travel nature. The study followed road side interviews, which was the most suitable method to be adopted for such study purpose. This was identified by an extensive literature survey. Pilot studies were conducted during midweek and weekends to identify the volume of walkers and motorists coming through the four gates of the university to get an idea on size of survey teams to conduct interviews and to decide how to locate survey teams around the entry gates during the main surveys.

Main surveys were carried out on a Saturday (weekend) and a Wednesday (midweek), from 8:00 to 18:00 hours covering a 10-hour survey duration. According to the questionnaire, the walkers and motorists coming to OUSL through all four gates were interviewed and contacted more than 1000 respondents. This survey has captured around $58 \%$ of total arrivals during the weekend and $56 \%$ during midweek. It was observed that a total of $51 \%$ of university community came through Nugegoda. Most of them came from Kotte Divisional Secretaries division (zone no 7). It was observed that from the total

*Corresponding should be addressed to Prof. K. S. Weerasekara, Department of Civil Engineering, The Open University of Sri Lanka, Sri Lanka

Email:kswee@ou.ac.lk

(D) https://orcid.org/0000-0002-7108-4374

(Received 25th April 2019; Revised 10th November 2019; Accepted 20th December 2019) (C) OUSL)

(C) (2) This article is published under the Creative Commons Attribution-Share Alike 4.0 International License (CC-BY-SA). and the original work is properly cited. 
arrivals, $82 \%$ (weekend) and 66\% (midweek) came from zone 7 . Out of the community coming to the University for Study Purposes during weekends, $51 \%$ were males and $48 \%$ females; during midweek, $54 \%$ were males and $46 \%$ females. Around $74 \%$ of community coming to OUSL use buses, while $9 \%$ come by trains.

As the final outcome of this study, a shuttle service of buses was designed to provide a better service to OUSL visitors during the rush hours (ie. 8:00 am to 10:00 pm). Shuttle services are proposed from some main towns. Through the study it was found that presently no adequate number of passengers use trains.

Key words: OD Pattern Study, OUSL Arrivals, OUSL Gate Study

\section{Introduction}

Origin destination surveys collect data regarding trip patterns, and such data can be used with other information to help transport planners to understand the needs of an area and develop appropriate sustainable transport solutions. To study the inflow pattern and travel modes of visitors to a particular location, it may become necessary to collect data as to where the traffic is coming from. In such transportation studies, it is often necessary to know the exact origin, time of the day when journeys are made, trip purpose and mode of travel. These studies are called Origin Pattern Studies. Most of these surveys are used in traffic planning at road junctions and mid-blocks. However, such a study can be used to analyse the inflow pattern of university visitors. A similar origin pattern survey has been conducted by Vandebona, et al., (1994, 1997) for KUR-RIN-GAI Campus in Sydney. This paper is the result of a similar Origin Pattern Study conducted at the OUSL Colombo Regional Centre and Main University, Nawala. The findings of this study is presented in this paper.

The Open University of Sri Lanka (OUSL) is the premier Open and Distance Learning institution in Sri Lanka where students can pursue their studies through the Open and Distance Learning (ODL) methodologies. The university is able to serve a large student population spread throughout the country. Currently, there are nearly 40,000 students studying at OUSL. The central campus and the Colombo Regional Center (CRC) are situated in Nawala (http://www.ou.ac.lk). However, most of those students regularly visit the CRC for their study 
purposes from all regions and provinces. They use several transportation modes to travel to OUSL from their home towns. The modes frequently used are: bicycle, motor cycle, car/van, 3-wheeler, bus, train, while there are those who also walk to the campus. The primary objective of this study is to obtain the origins of OUSL users coming into CRC and the main university Nawala and study their arrival patterns and obtain an understanding of the characteristics of these visitors.

\section{Objective}

The objective of this study is to observe the travel origins of commuters arriving at OUSL Nawala, and study their travel patterns and their travel modes. Then by analysing the travel patterns and modes the study intends to improve the travel time of the commuters by proposing a shuttle bus service during busy hours between OUSL and major commuter collecting points.

\section{Theoretical Framework}

An origin \& destination demand matrix is a vector that denotes the average number of trips going from origin to a destination point (Zuylen and Willumsen, 1980). Similar studies conducted by Vandebona et al. $(1994,1997)$ has investigated the origin pattern of those who came to KUR-RIN-GAI Campus with proposing second access to the campus from Lady Game Drive.

Traffic studies are carried out to analyze the traffic characteristics. These studies help to decide the geometric design features of traffic control for safe and efficient traffic movement (Patel, 2006). The various traffic survey studies generally carried out are: traffic volume studies, speed studies, spot speed studies, speed and delay studies, origin and destination studies, traffic flow characteristics, traffic capacity studies, parking studies and accident studies.

Origin pattern data is of prime importance to understand the travel patterns and the associated demands on a transportation network over the entire region. These surveys collect valuable data related to trips. This data is normally used as the basic input to transportation models developed to support the decision-making process of the transport agencies (Manikantaswamy, 2005. From: www.slideshare.com). Origin pattern surveys provide a detailed picture of the trip patterns. These surveys collect valuable data related to trips in order to; understand travel patterns and characteristics, judge the adequacy of existing 
routes, locate new proposed roads, locate parking places, locate expressways, regulate movement of heavy vehicles, and locate new bridge as per the traffic demand. Historically, there have been considerable research and studies focusing on origin pattern data collection methodologies including; roadside interviews, mail-back postcard surveys, telephone surveys, license plate mail back surveys, home interview surveys, online surveys, tag surveys and combinations of the above methods.

This commuter travel pattern study of OUSL Nawala is conducted with the primary objective to improve the traveling facilities for OUSL users. It aims to minimize the traveling time, design suitable bus routes for users who use buses, propose shuttle service, propose suitable train schedule for relevant commuters and study the details of arriving community to the university. A number of survey methods were considered prior to the selection of the present methodology, which is articulated in the literature review, to capture the OUSL users to get their origin-distribution. A method which is not much resource intensive, but expected to provide good response rate for prescribed questionnaire with complete information in short duration has to be selected. Therefore, road side interviews was selected as most suitable way to conduct the survey at CRC and the main university in Nawala origin pattern study. Hence it was the intention to maximize the survey sample as much as possible, if not to $100 \%$.

\section{Zoning, Desire Lines and Nodes}

Zoning is the process of dividing land in a municipality into zones (e.g. residential, industrial). Areas of land are divided by appropriate authorities into zones within which various uses are permitted. Thus, zoning is a technique of land-use planning as a tool of urban planning used by local governments in most developed countries.

Desire lines are drawn so that they clearly show on a map the flows of people or goods from point to point based on the values from a matrix. Zones represent trip origin and destination areas while desire lines connect the centroids of the origin and the destination zones, and thereby denote where people desire to go between zones. They represent the straight-line route between A and B that would be taken, if it were not for obstacles such as buildings and curved roads getting in the way. The width of such desire line is drawn proportional to the number of trips in both directions. The desire line density map easily helps decide the actual desire of the road users and thus facilitates the finding of the 
necessity of a new road link, a diversion, a by-pass or a new bridge (Kanna and Justo, 2011).

Nodes in physical transport data are zero-dimensional features (points) among the predominantly one-dimensional features (lines) that comprise the network. There are two types of transport nodes. They are: (1) nodes not directly on the network such as zone centroids or individual origins and destinations (such as houses and workplaces); (2) nodes that are a part of transport networks representing individual pathways, or intersections between pathways (junctions) and points for entering or exiting a transport network (such as bus stops and train stations).

\section{Methodology}

\section{Pilot Survey}

It has to be stated that the term 'walkers' means all those persons entering the university premises through the 4 gates by foot, although they may have used any transport mode to arrive at the university.

A pilot study was conducted to obtain an initial feel of the number of walkers and motorists coming in to the university, and the gate operations to find out the size of survey teams to be deployed during the survey and to ensure their smooth operation during the surveys. During the pilot survey, at all 4 gates, the incoming walkers and vehicles were counted at 15-minute intervals from 8:00 am to 10:00 am, when the inflow was at its maximum. These counts were taken on Wednesday (midweek day) and Saturday (weekend) since the arrivals are different in week days and weekends.

At all 4 gates (see Figure 1) separate inflows of walkers and vehicles were obtained during midweek and the weekend and the peak flows observed are indicated below. It was also found that questionnaire survey took around 2 minutes to interview a single respondent. Hence, based on the inflow, the size of the survey teams for the 4 gates was finalized. 


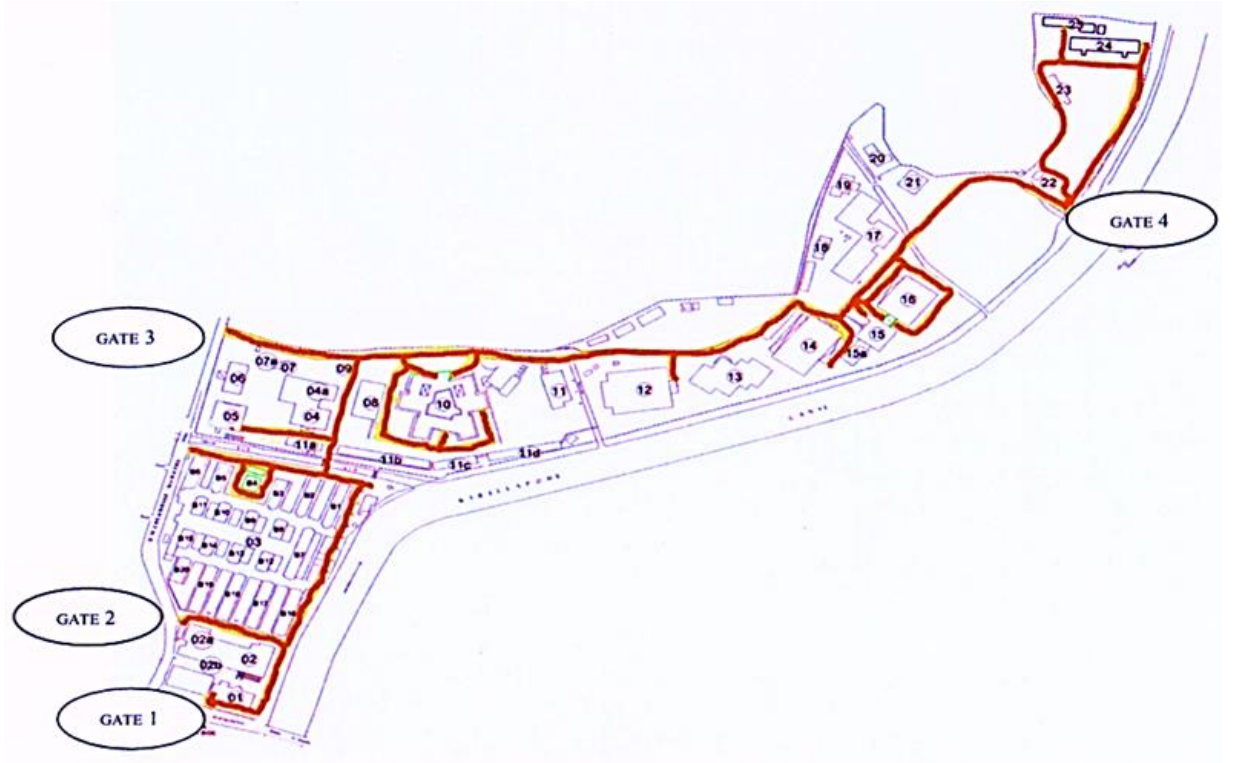

Figure 1. Locations of four gates

Table 1. Survey Teams at the four gates

\begin{tabular}{|l|l|c|c|}
\hline Gate No. & Activity of the Counter & No. & Total \\
\hline Gate 01 & Total arrival counters & 01 & \\
& Interviewers & 06 & 07 \\
\hline Gate 02 & Total arrival counters & 01 & \\
& Interviewers (walk-in) & 02 & \\
& Interviewers (drive-in) & 02 & 05 \\
\hline Gate 03 & Total arrival counters & 01 & \\
& Interviewers (walk-in) & 02 & \multirow{2}{*}{05} \\
\hline Gate 04 & Interviewers (drive-in) & 02 & \\
& Total arrival counters & 01 & 05 \\
& Interviewers (walk-in) & 02 & \\
& Interviewers (drive-in) & 02 & \multirow{2}{|c|}{05 No. } \\
\hline
\end{tabular}


Hence, to conduct the survey at all the 4 gates in one day 22 survey team members were required

\section{Main Survey}

Main survey was conducted using the road-side interview method which is justified in the literature review. The road-side interview method requires collecting responses to questionnaire with very high response rates and completing information within a short duration on the road way by stopping motorists and walkers at the interview stations by a group of interviewers. By analyzing the pilot survey data, it was decided to interview a sample of at least 1000 entrants per day.

The following steps were followed during the road side survey:

1. Preparing two different questionnaires for walkers and motorists

2. Selecting interview points at the site

3. Deciding the interview dates

4. Deciding the survey period

5. Identifying survey team and materials

6. Obtaining the permission from university authorities

7. Conducting brief training session for the survey team

8. Collecting the data from the questionnaires

A predefined series of questions was used (see Figure 2 and Figure 3) to collect information from individuals to identify origin pattern, peak time and mode of transport and obtain the outcomes at four gates. For those two categories, different questionnaires were required from walkers and motorists. 


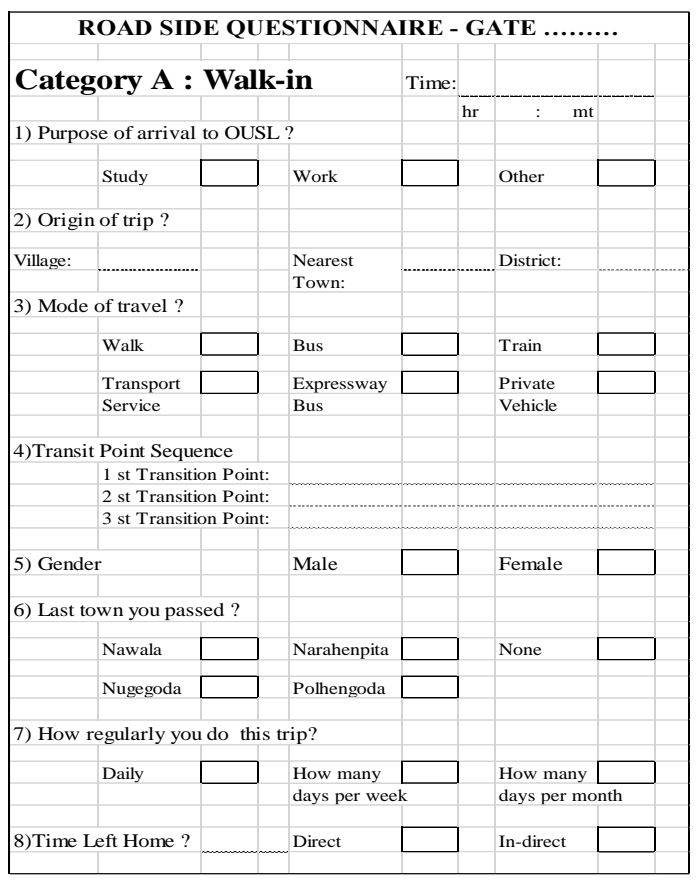

Figure 2

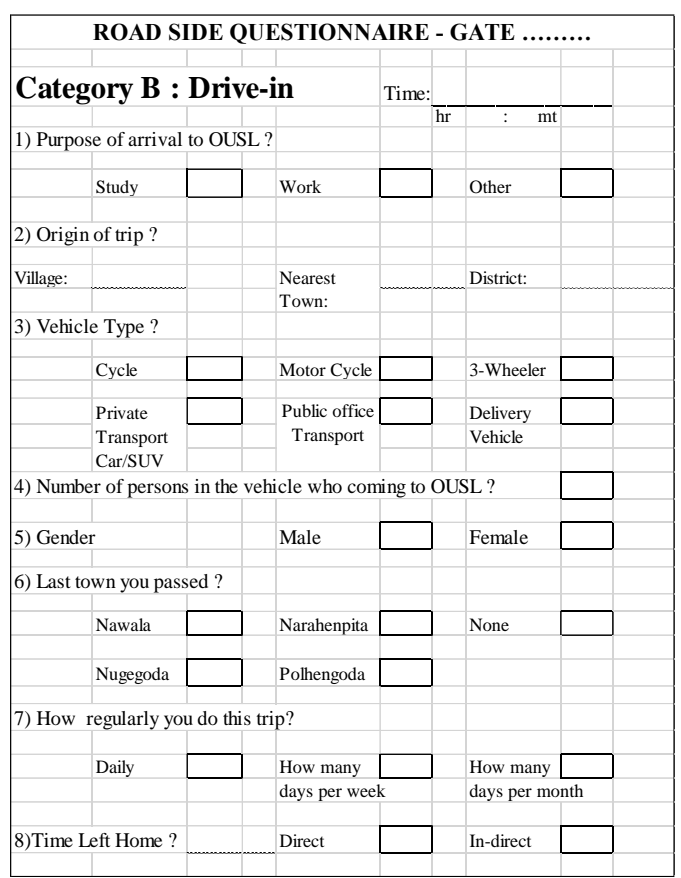

Figure 3

Predefined series of questions (Figure 2 and Figure 3)

The survey teams attempted to approach all pedestrians walking through the gates and all the motorists coming in to capture the maximum number of arrivals to the university. Interviewers recorded the responses in a simple tabulation during the survey. The arrival time of each respondent was recorded. When walkers arrived in large groups, the survey staff could only contact a limited number of persons from that group. This phenomenon was specially accounted for in the design of the survey and a separate count was taken for the total arrivals (both walkers and motorists) at every 15-minute interval. 

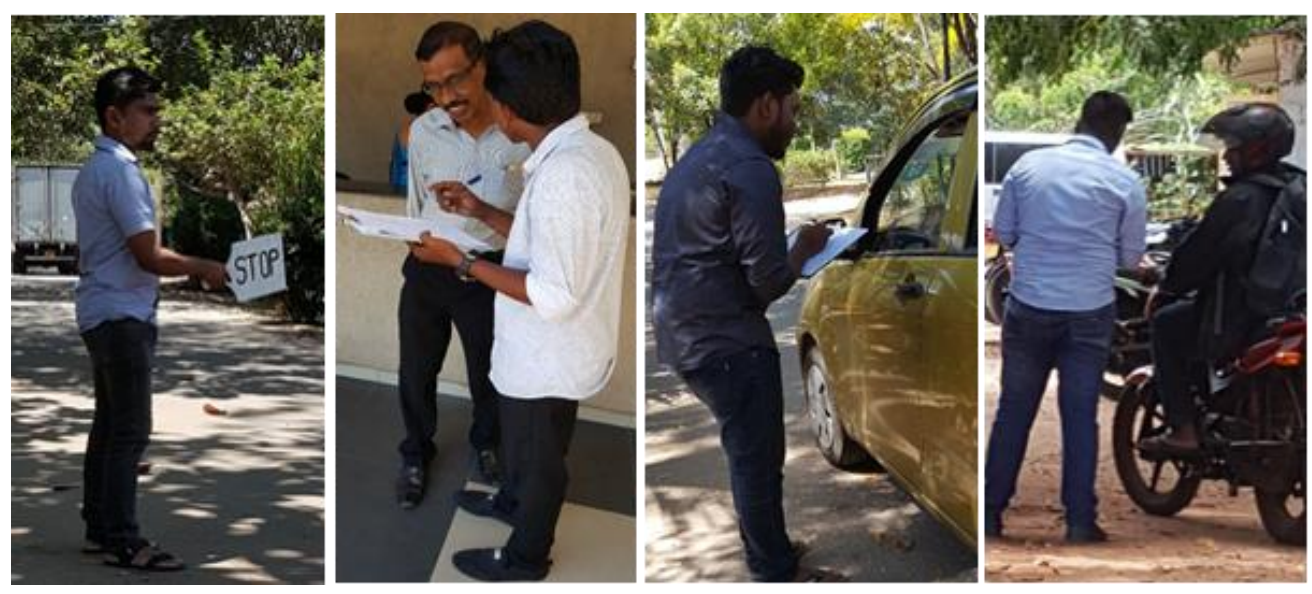

Figure 4. Survey in progress

\section{Results}

\section{Nature of Survey Sample}

The results of the survey were analyzed separately for (a). Weekend arrivals, and (b). Mid-week arrivals.

(a). Weekend arrivals

The survey team questioned 870 out of 1,510 of those who arrived at OUSL by walking through the 4 gates, which was a response rate of $57.6 \%$. Similarly, 246 vehicle drivers were interviewed out of 424 total arrivals through the 4 gates which is a response rate of $58 \%$. Table 2 indicates the percentages of interviewed samples at the 4 gates separately. Hence the samples interviewed have been more than $50 \%$ at all 4 gates on both days. 


\section{WEEKEND}

\section{Interviwed}

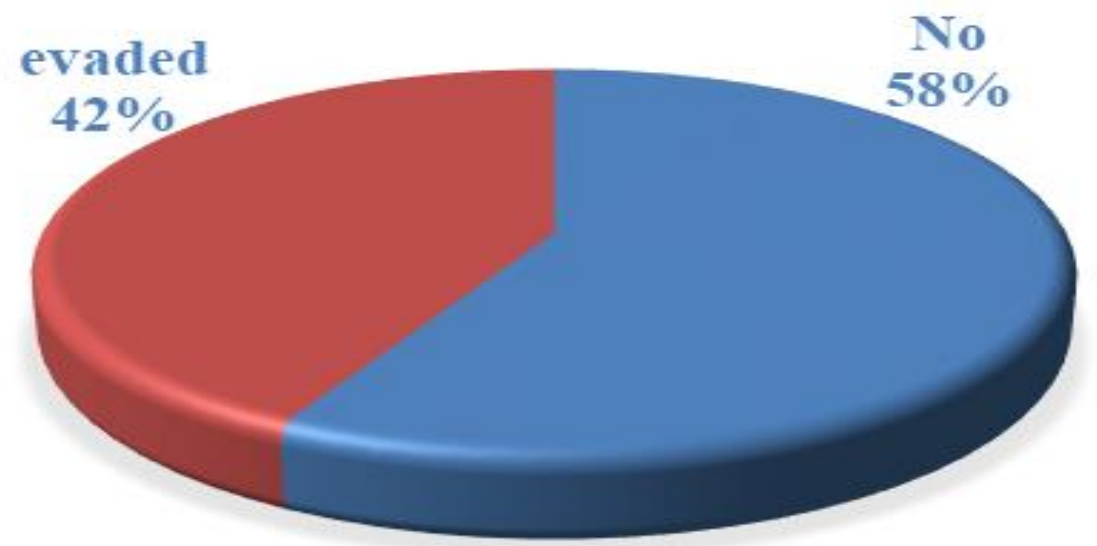

Figure 5. Interview percentage during the weekend

Table 2. Weekend interview chart

\begin{tabular}{|c|c|c|c|c|c|c|}
\hline & \multicolumn{3}{|c|}{ WALK-IN } & \multicolumn{3}{c|}{ DRIVE-IN } \\
\cline { 2 - 7 } & $\begin{array}{c}\text { Total } \\
\text { Arrived }\end{array}$ & $\begin{array}{c}\text { No of } \\
\text { Interviewed }\end{array}$ & $\%$ & $\begin{array}{c}\text { Total } \\
\text { Arrived }\end{array}$ & $\begin{array}{c}\text { No of } \\
\text { Interviewed }\end{array}$ & $\%$ \\
\hline GATE 1 & 1046 & 615 & 58.8 & - & - & - \\
GATE 2 & 296 & 153 & 51.7 & 67 & 35 & 52.2 \\
GATE 3 & 107 & 67 & 62.6 & 210 & 128 & 61.0 \\
GATE 4 & 61 & 35 & 57.4 & 147 & 83 & 56.5 \\
\hline TOTAL & 1510 & 870 & 57.6 & 424 & 246 & 58.0 \\
\hline
\end{tabular}



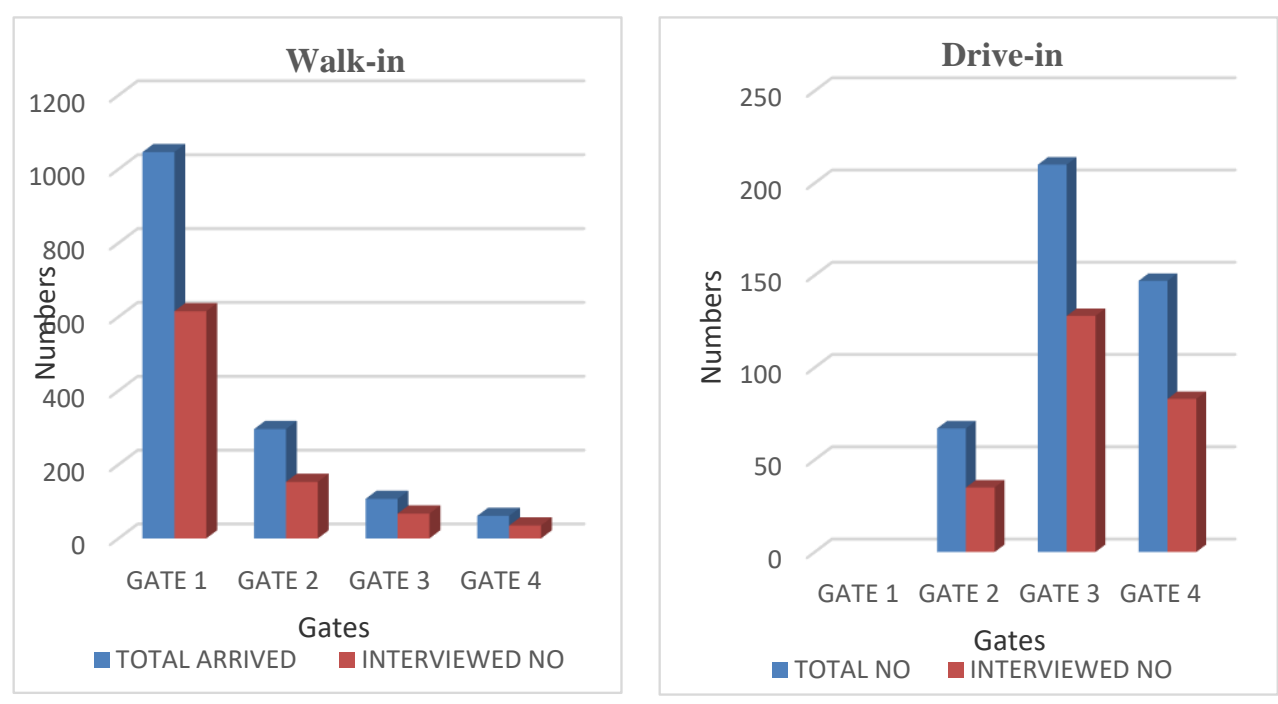

Figure 6. Weekend interview capacities

Figure 7 shows the count of walkers on Saturday at every 15-minute interval. 8:15 am to 9:15 am is the peak time in the campus.

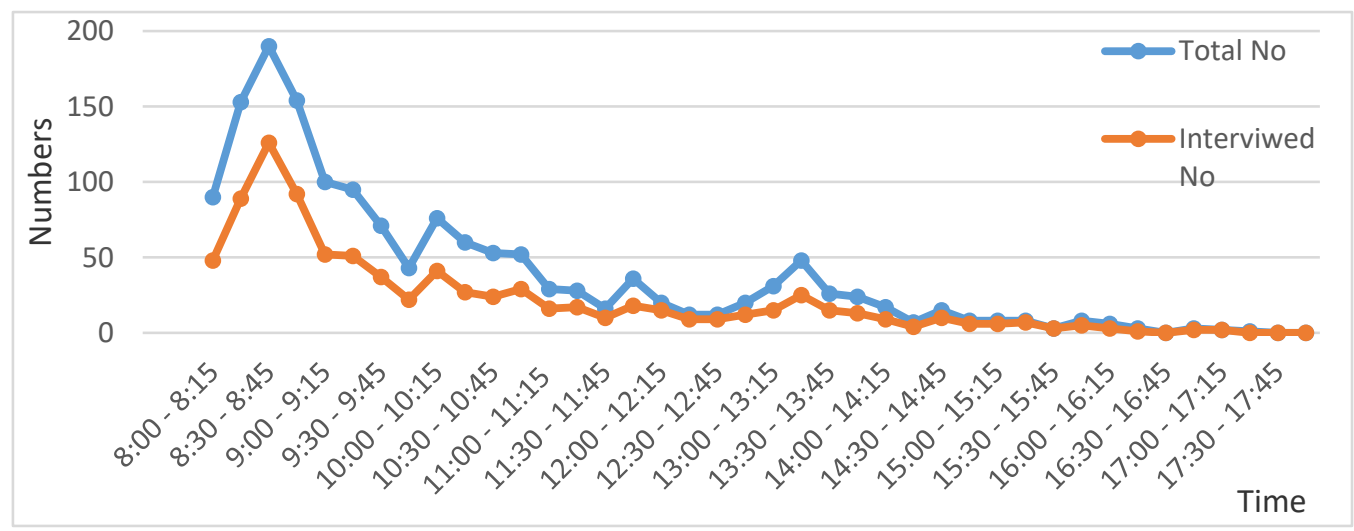

Figure 7. Weekend walk-in at all four gates (Interviewed number and total arrivals)

The Figure 8 shows the count of Vehicles on Saturday at every 15 minutes. 
From $8: 15$ to $9: 15$ am is the peak time in the campus.

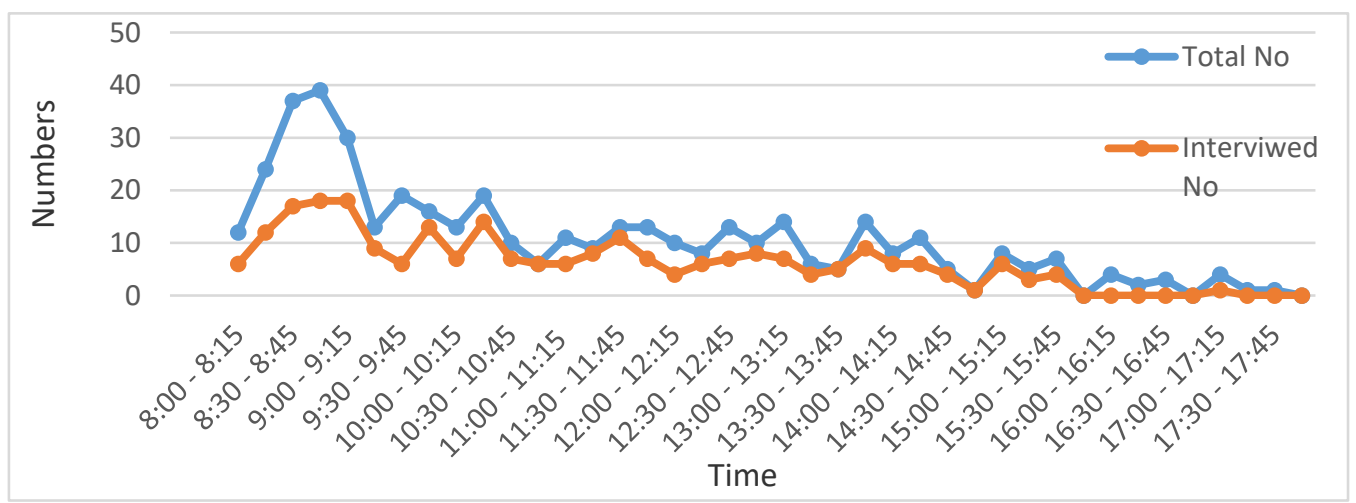

Figure 8. Weekend drive-in at all four gates (Interviewed number and total arrivals)

(b). Midweek arrivals

The survey team questioned 837 out of 1,261 of those who arrived at OUSL by walking through the 4 gates, this is a response rate of $66.4 \%$. Similarly, 339 vehicle drivers were interviewed out of 821 total arrivals through the 4 gates which is a response rate of $41.3 \%$. Table 2 indicates the percentages of interviewed samples at the 4 gates separately. Hence samples interviewed have been more than $35 \%$ at all 4 gates on both days.

\section{MIDWEEK}

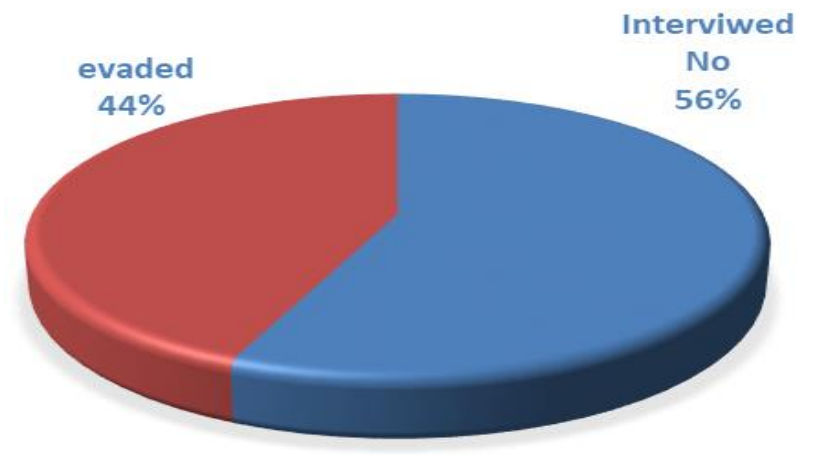

Figure 9. Interview percentage at Midweek 
Table 3. Midweek interview chart

\begin{tabular}{|c|c|c|c|c|c|c|}
\hline & \multicolumn{3}{|c|}{ WALK-IN } & \multicolumn{3}{c|}{ DRIVE-IN } \\
\cline { 2 - 7 } & $\begin{array}{c}\text { Total } \\
\text { Arrived }\end{array}$ & $\begin{array}{c}\text { No of } \\
\text { Interviewed }\end{array}$ & $\%$ & $\begin{array}{c}\text { Total } \\
\text { Arrived }\end{array}$ & $\begin{array}{c}\text { No of } \\
\text { Interviewed }\end{array}$ & $\%$ \\
\hline GATE 1 & 859 & 586 & 68.2 & - & - & - \\
GATE 2 & 169 & 113 & 66.9 & 73 & 47 & 64.4 \\
GATE 3 & 168 & 98 & 58.3 & 510 & 204 & 40.0 \\
GATE 4 & 65 & 40 & 61.5 & 238 & 88 & 37.0 \\
\hline TOTAL & 1261 & 837 & 66.4 & 821 & 339 & 41.3 \\
\hline
\end{tabular}
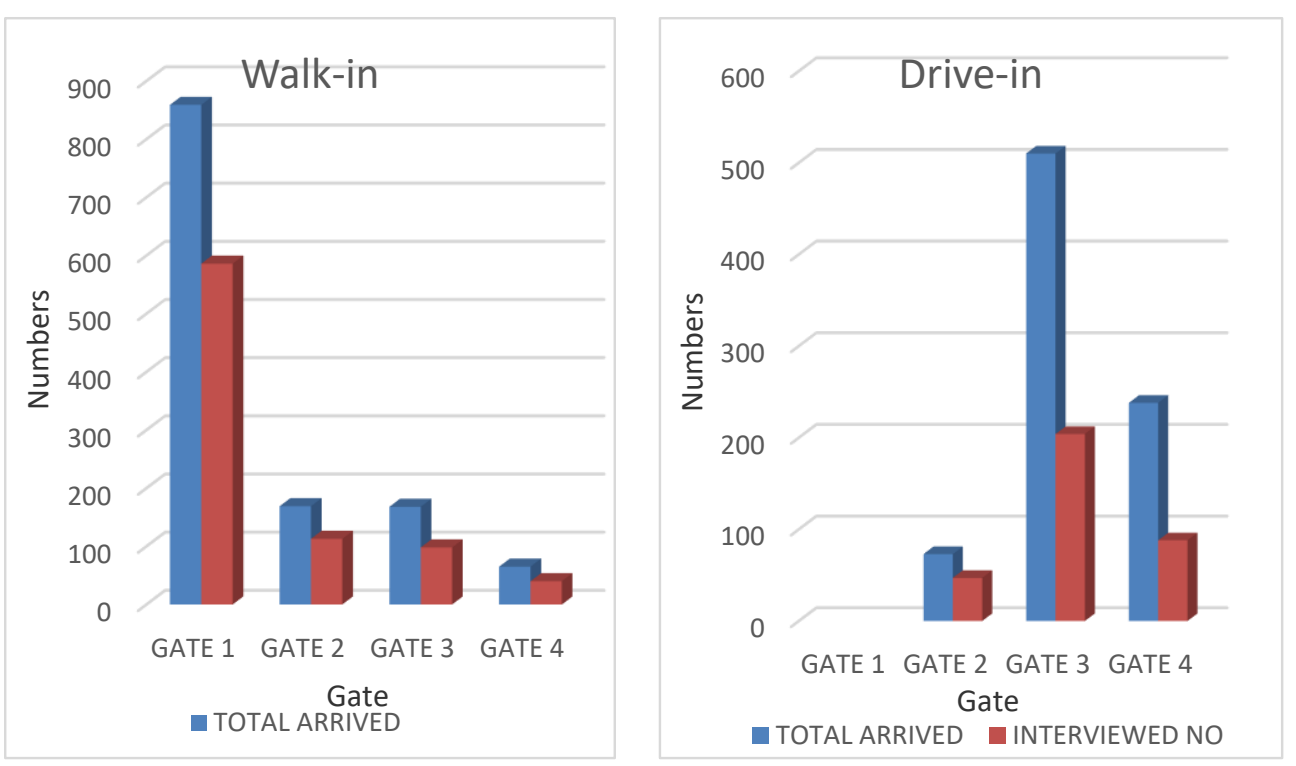

Figure 10. Midweek interview capacities

Figure 11 shows the count of walkers on Wednesday every 15 minutes. 8:30 am to 9:30am is the peak time in the campus. 


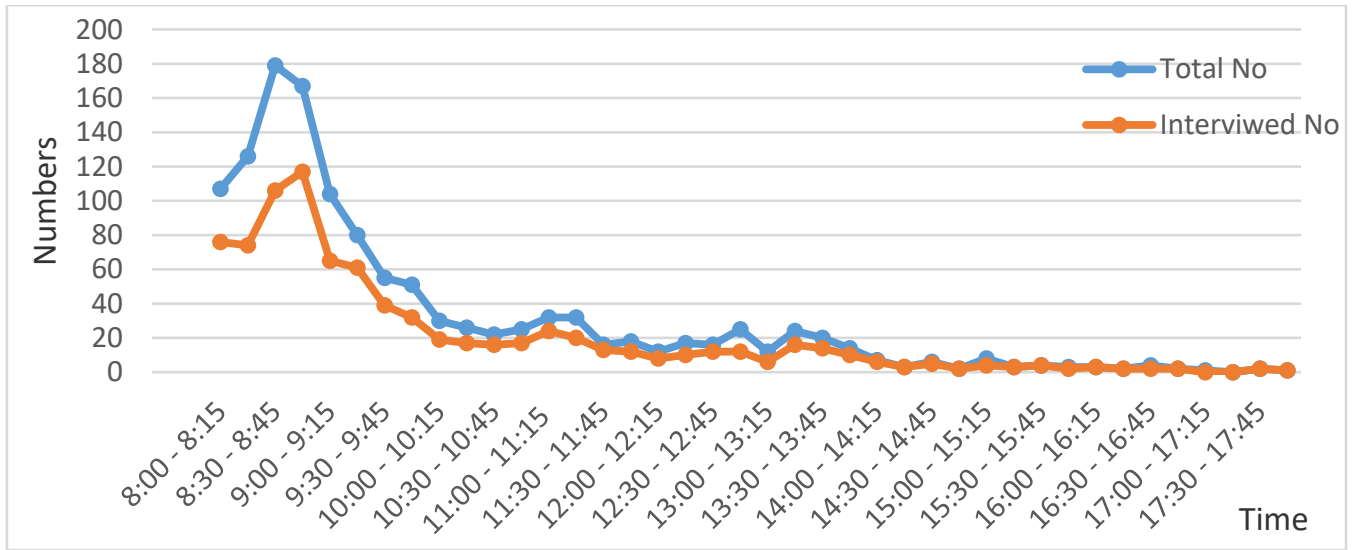

Figure 11. Midweek walk-in at all four gates (Interviewed number and total arrivals)

Figure 12 shows the count of vehicles on Wednesday every 15 minutes. 8:30 am to 9:30 am is the peak time in the campus.

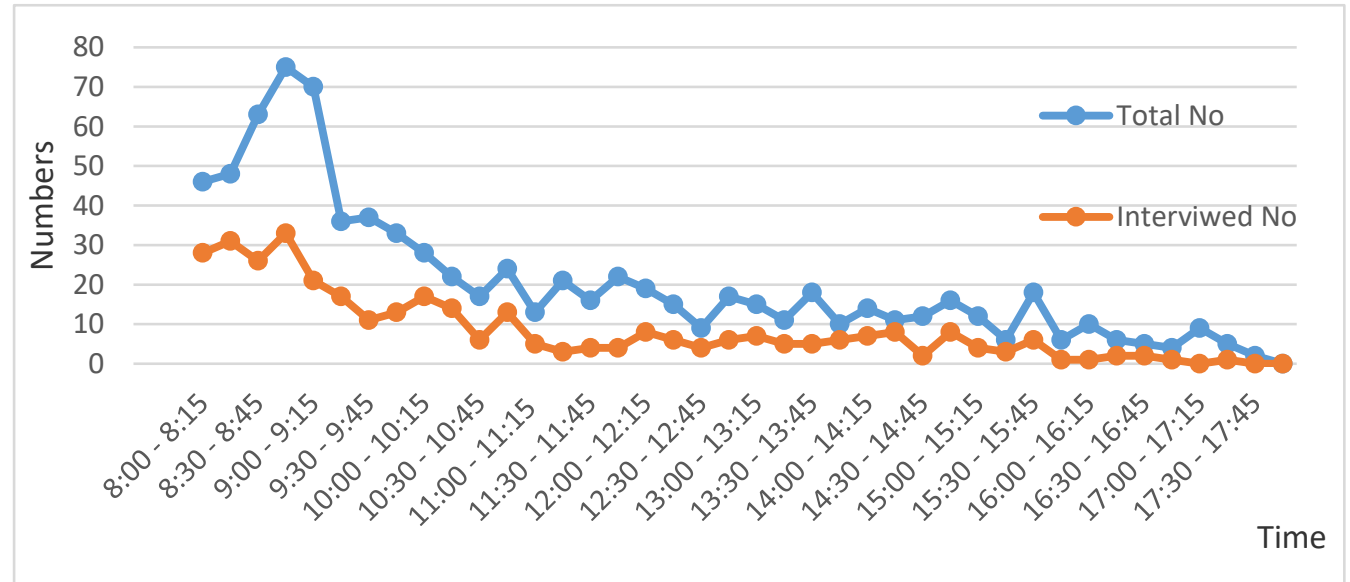

Figure 12. Midweek drive-in at all four gates (Interviewed number and total arrivals)

\section{Purpose to Arrival}

The purpose of coming to OUSL can be mainly categorized as: study, work, other (category 'other' includes all the other visitors to OUSL). 

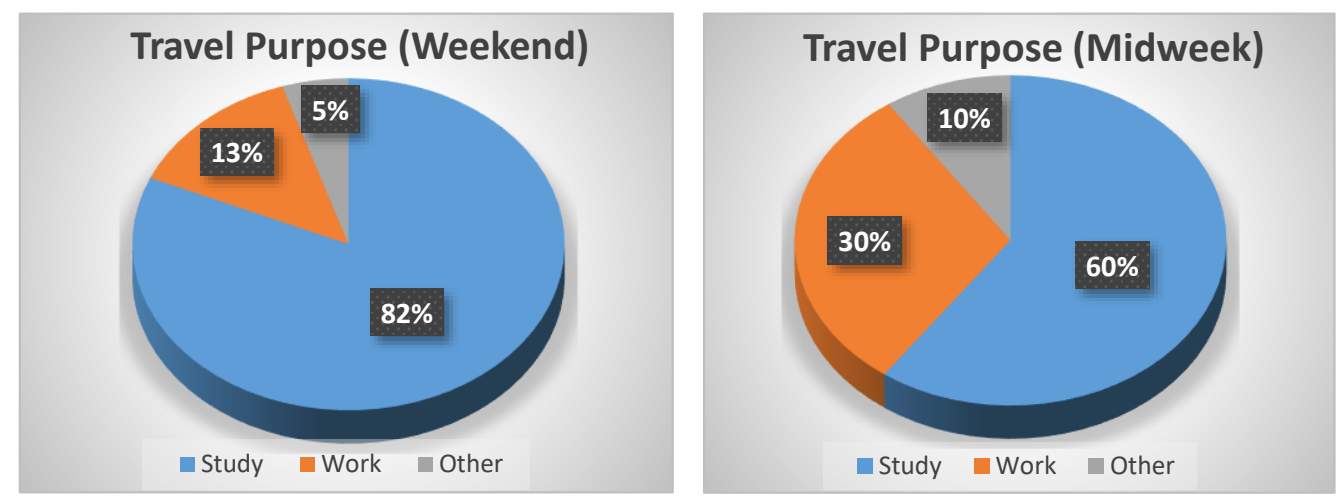

Figure13. Percentages of purpose to total arrival

During the weekend, $82 \%$ of visitors came for study purposes, $13 \%$ for work, and $5 \%$ for other purposes. During midweek, $60 \%$ of visitors came for study purposes, $30 \%$ for work, and $10 \%$ for other purposes.
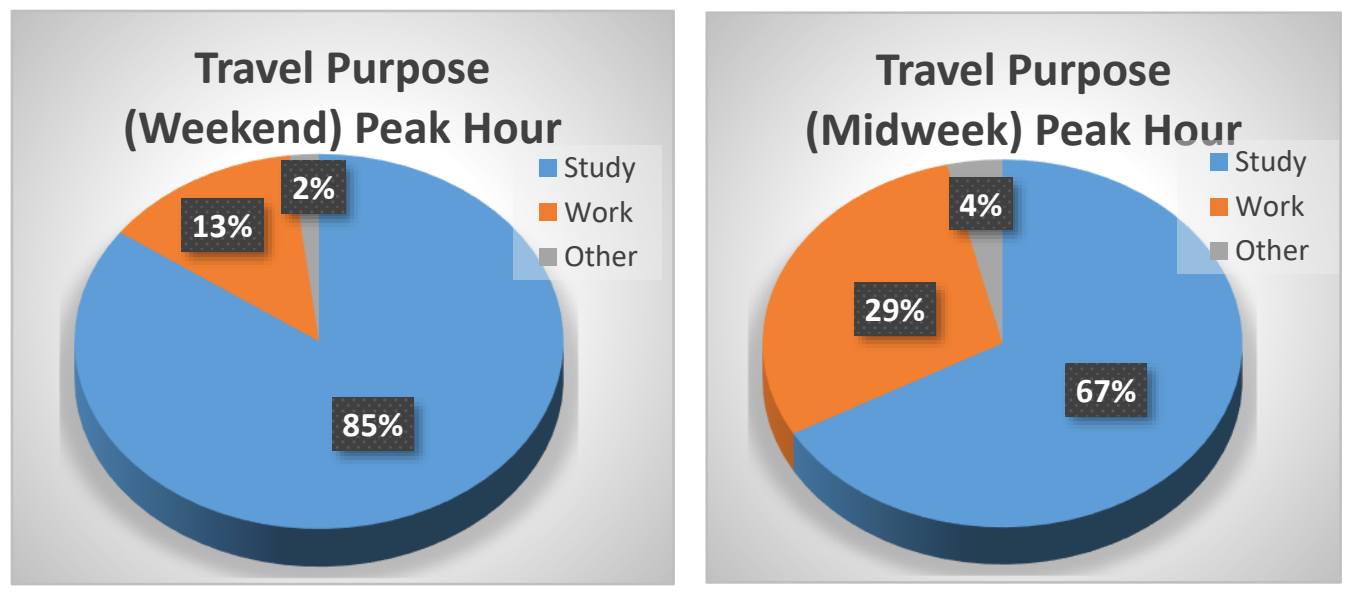

Figure 14. Percentages of purpose at peak hours

When considering the peak time, the purpose of arrival is shown in Figure 14:

According to the peak hour pie charts, during the weekend $85 \%$ of the visitors came for study purposes, $13 \%$ for work, and $2 \%$ for other purposes. During midweek, $67 \%$ of the visitors came for study purposes, 
$29 \%$ for work, and $4 \%$ for other purposes. There is significant reduction of visitors who would frequently come to OUSL for purposes such as delivery, collect certificates, etc. during peak hours.

\section{Last Town Passed}

All visitors coming to OUSL have to pass one of these towns: Nawala, Narahenpita, Nugegoda, Polhengoda or 'none'. The pie charts given below show the results (category 'none' consists of the people living in close proximity to OUSL).
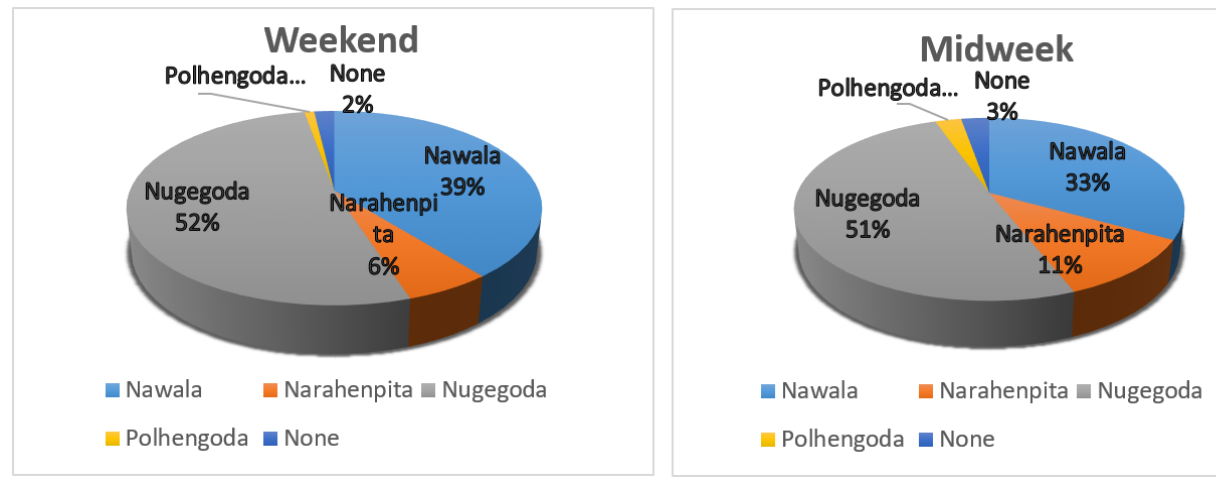

Figure 15. Percentage of last town passed out of total arrivals

The analysis shows that during the weekend and midweek most of visitors ( $52 \%$ in weekend, $51 \%$ in midweek) come through Nugegoda. Peak hour percentages are similar to the above.

\section{Mode of Travel}

The commuters coming to OUSL use several travel modes. The pie charts next page show it clearly. 

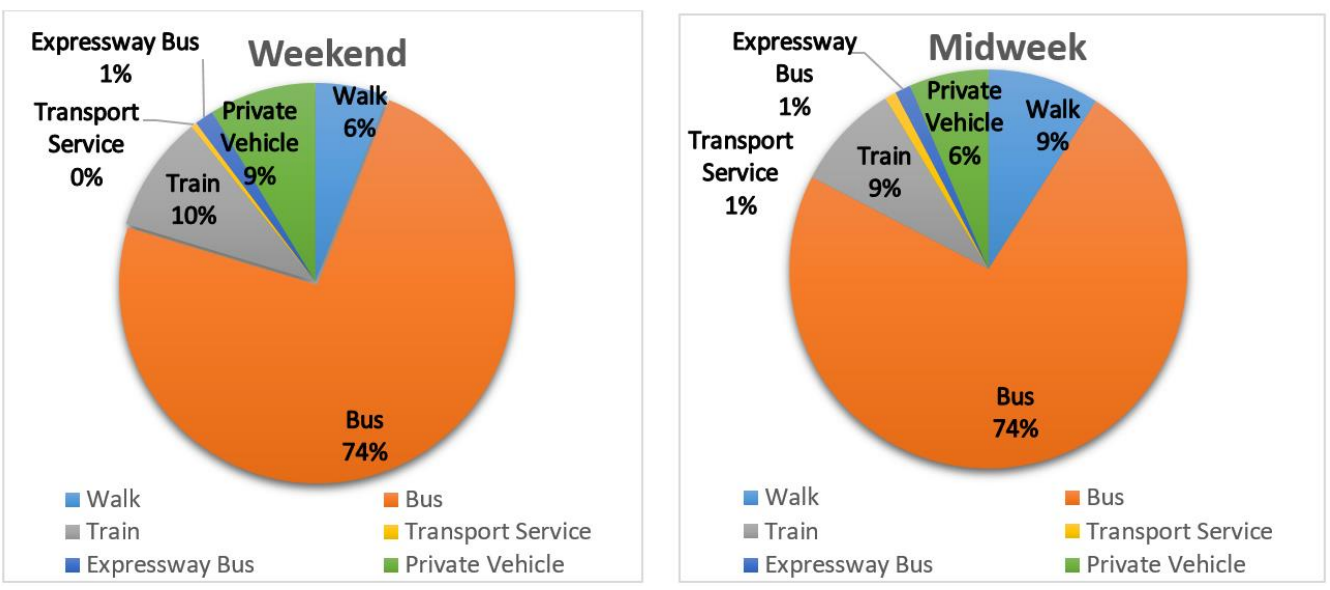

Figure 16. Percentage of Travel Mode

The analysis shows that during the weekend $74 \%$ visitors used the bus, $10 \%$ train, $9 \%$ private vehicle, $6 \%$ walked and $1 \%$ expressway bus to come to OUSL. During midweek $74 \%$ visitors used the bus, $9 \%$ walked, $9 \%$ train, $6 \%$ private vehicle, $1 \%$ expressway bus and $1 \%$ transport service to come to OUSL.

\section{Results}

As a part of this study analysis includes zoning the Sri Lanka map relating to study objectives, expanding number of subjects were interviewed to identify corresponding arrival origins and to construct desire lines from every zone to OUSL. The intention of obtaining the origin patterns was to propose shuttle service. Analysis was extended to further investigate the arrival pattern of users of OUSL Nawala with their travel origins and travel mode patterns. For this purpose, the data collected from survey and other sources were carefully analyzed. To make things more meaningful in the context of the study objectives, it was decided to divide Sri Lanka and the Western Province into several zones. Analysis consists of following steps:

(a). Divide Sri Lanka in to reasonable zones

(b). Calculate expansion factors and tabulate the real data for different zones with 15-minute intervals

(c). Identify the maximum arrival zones at total duration and peak time 
(d). Develop the desire line maps

(e). Propose the shuttle service

\section{Zoning}

To develop a pattern of arrival that correlates to study objectives it was decided to divide Sri Lanka and Western Province into several zones. For this purpose, the Western Province Divisional Secretariat Division (DSD) map and all island map collected from the Survey Department were used. Proximity to the University was the main consideration in this segmentation method. For this the information was short listed. It was decided to divide Sri Lanka in to 50 broad areas. Since the university is situated in the Western Province, it was divided into divisional secretariat divisions. Western province consists of 3 districts; Colombo, Gampaha and Kalutara. Colombo district consists of 13 divisional secretariat divisions, Gampaha district 13 and Kalutara district 14. They are indicated from zone 1 to zone 40. Nearer districts to the Western Province such as, Puttlam, Kurunegala, Kegalle and Ratnapura are taken as zone 41 - zone 44. Several faraway districts were taken altogether to create provinces such as Southern, Uva, Eastern, North Central and the Northern indicated by Zone 45 - zone 50 . To assume the reasonable quantity of arrivals from these separate zones, the data were multiplied using the expansion factor.

\section{Expansion factor}

To arrive at an accurate number of arrivals to OUSL from these separate zones, the real data collected from the survey were multiplied by an expansion factor. Expansion factors which were the ratio of the number of interviewed and the corresponding arrivals during 15-minute counting intervals that were counted. These factors are used to expand origin at survey zones.

$$
\text { Expansion Factor }=\frac{\text { Total number of arrivals }}{\text { Number of interviwed }}
$$

There are two kinds of expansion factors in tabulations called Total Expansion Factor and Peak Total Expansion Factor. The total expansion factor is calculated considering the total arrivals during the survey time (8:00 to 18:00). The peak total expansion factor is calculated considering the total arrivals during the peak time (8:15 to 9:15). 
According to Figure 17, the maximum number of 158 walkers came from zone 07 Kotte Divisional Secretariat Division.

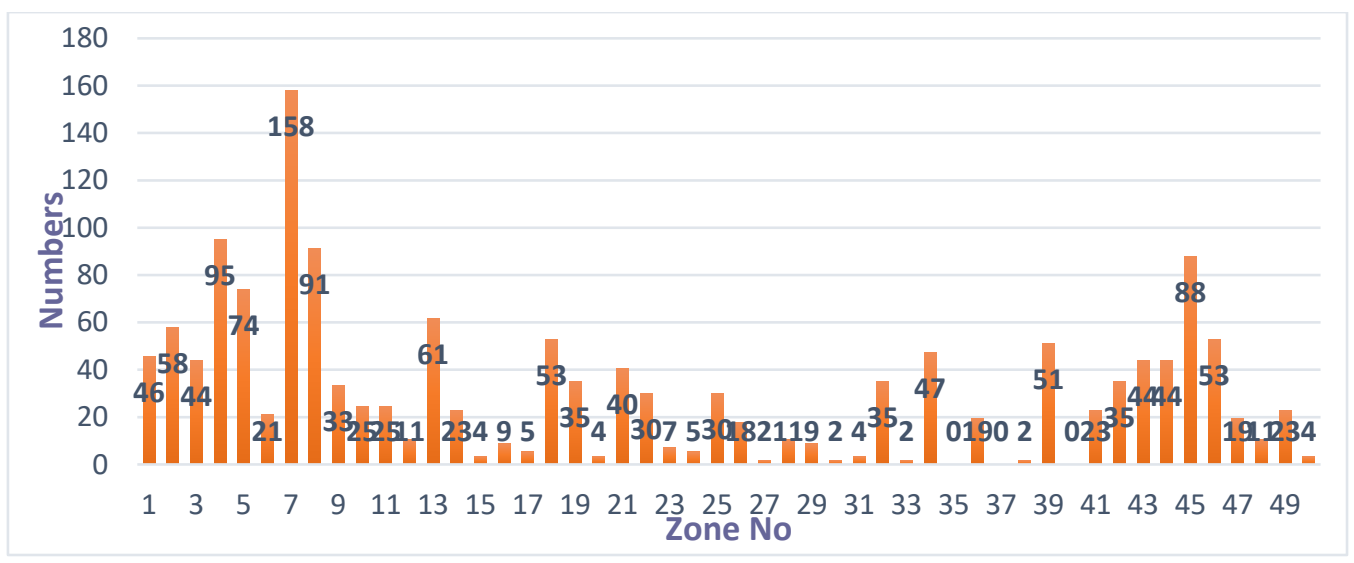

Figure 17. Weekend walk-in zone capacity

According to Figure 18, the maximum number of 98 vehicles came from zone 07 Kotte Divisional Secretariat Division.

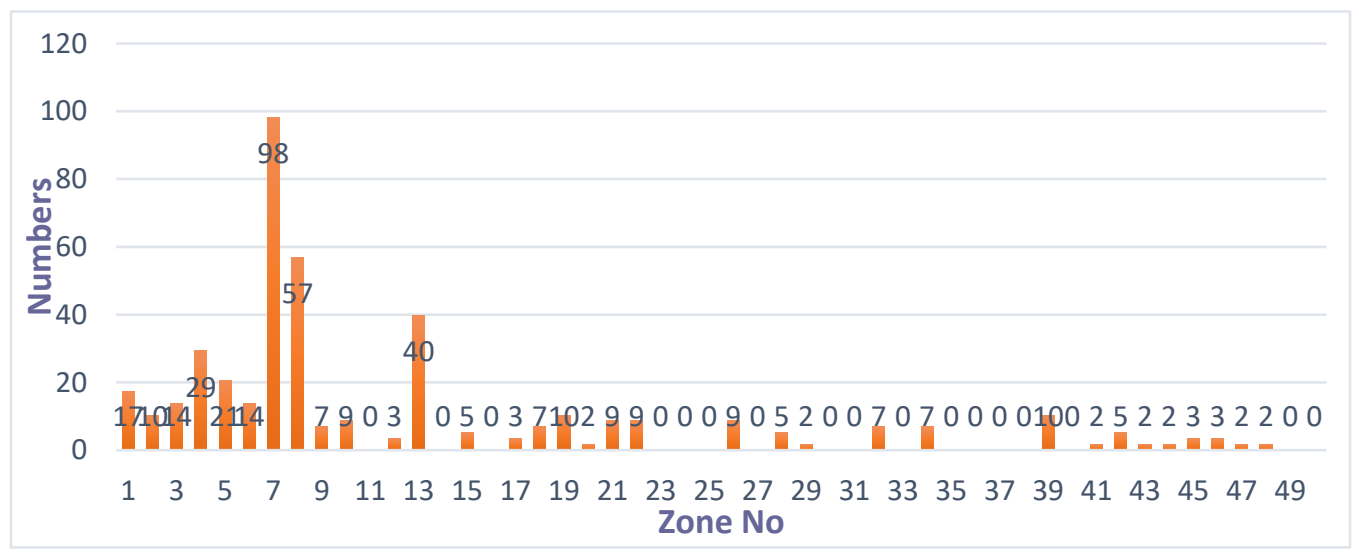

Figure 18. Weekend drive-in zone capacity 
According to Figure 19, the maximum number of 176 walkers came from zone 07 Kotte Divisional Secretariat Division.

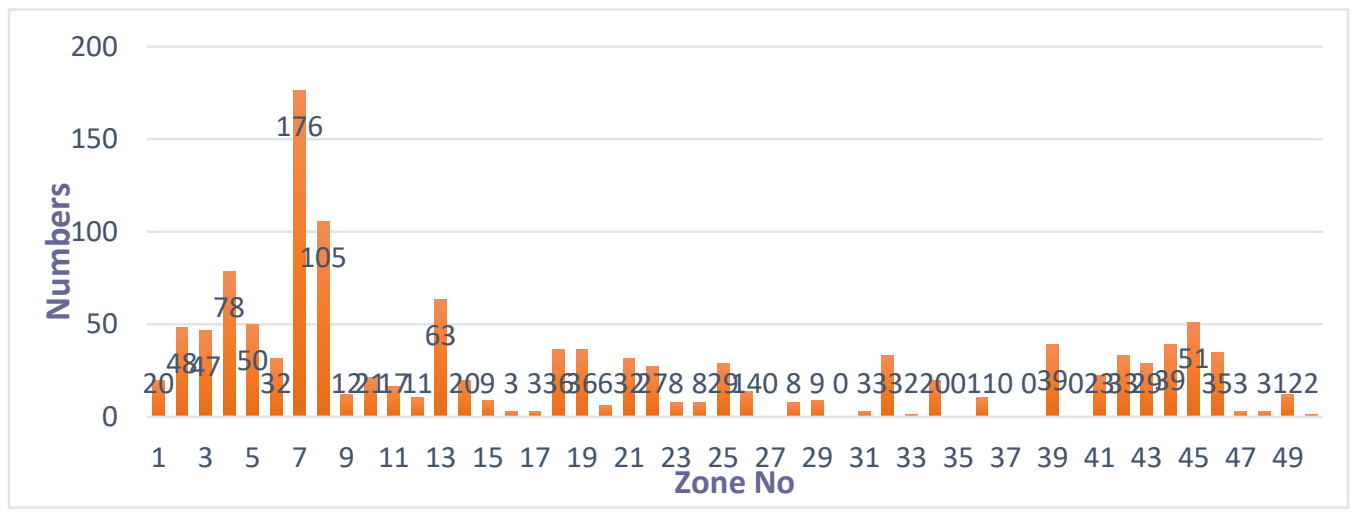

Figure 19. Midweek walk-in zone capacity

According to Figure 20, the maximum number of 174 vehicles came from zone 07 Kotte Divisional Secretariat Division.

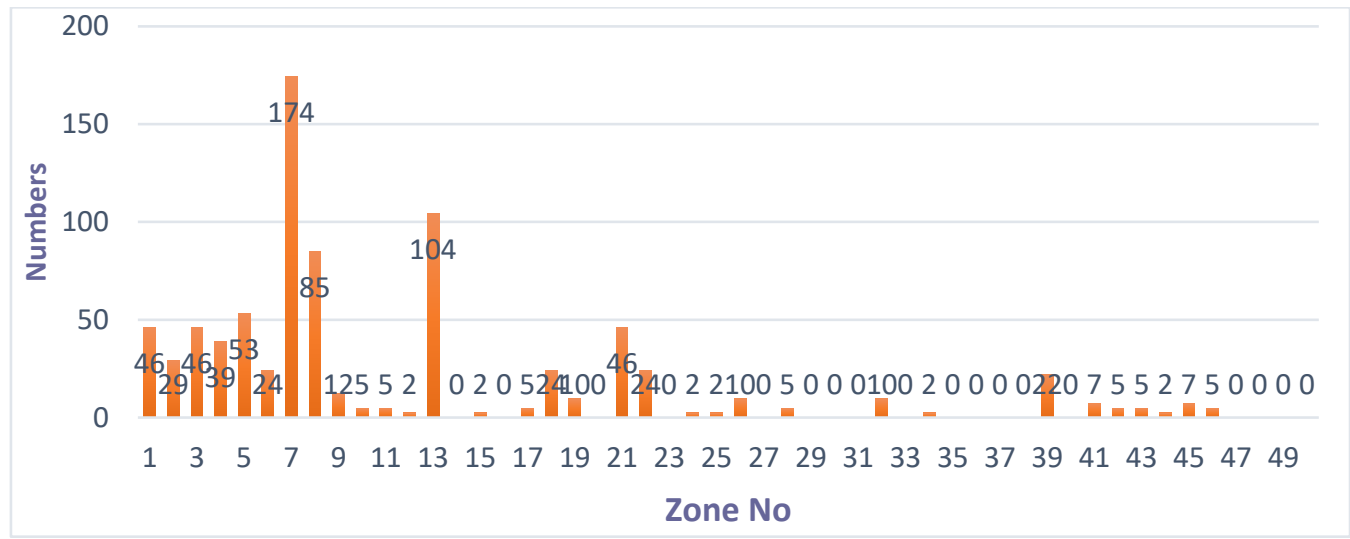

Figure 20. Midweek drive-in zone capacity

\section{Desire Lines}

Desire lines are used to illustrate on a map the flows of people or goods from point to point based on the values from a matrix. Desire line is a straight line on a map representing the movement of people and goods from region to region. They show movements from any zone to OUSL. The nucleus of each and every zone was located to design the desire lines. Every desire line starts from the nucleus of the zone (Kanna and Justo, 2011). Table 4 shows nucleus of zones: 
Table 4. Zones and nucleus points

\begin{tabular}{|c|c|c|c|c|c|}
\hline $\begin{array}{l}\text { Z̊ } \\
\text { ํํㅇ }\end{array}$ & Zone & Nucleus Point & 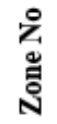 & Zone & Nucleus Point \\
\hline 1. & Colombo D.S. & Pettah & 26. & Wattala D.S. & Katunayaka \\
\hline 2. & Dehiwala D.S. & Dehiwala & 27. & Agalawatta D.S. & Agalawatta \\
\hline 3. & Homagama D.S. & Homagama & 28. & Bandaragama D.S. & Bandaragama \\
\hline 4. & Kaduwela D.S. & Malambe & 29. & Beruwala D.S. & Aluthgama \\
\hline 5. & Kesbewa D.S. & Piliyandala & 30. & Bulathsinhala D.S. & Bulathsinhala \\
\hline 6. & Kolonnawa D.S. & Mulleriyawa & 31. & Dodangoda D.S. & Neboda \\
\hline 7. & Kotte D.S. & Rajagiriya & 32. & Horana D.S. & Horana \\
\hline 8. & Maharagama D.S. & Maharagama & 33. & Ingiriya D.S. & Ingiriya \\
\hline 9. & Moratuwa D.S. & Moratuwa & 34. & Kaluthara D.S. & Kaluthara \\
\hline 10. & Padukka D.S. & Padukka & 35. & Madurawela D.S. & Anguruwatota \\
\hline 11. & Rathmalana D.S. & Mt. Lavenia & 36. & Mathugama D.S. & Mathugama \\
\hline 12. & Seethawaka D.S. & Awissawella & 37. & Millaniya D.S. & Galpatha \\
\hline 13. & Thimbirigasyaya D.S. & Borella & 38. & Palinda Nuwara D.S. & Banduraliya \\
\hline 14. & Attanagalla D.S. & Warakapola & 39. & Panadura D.S. & Panadura \\
\hline 15. & Biyagama D.S. & Biyagama & 40. & Walallawita D.S. & Pelawatta \\
\hline 16. & Divulapitiya D.S. & Divulapitiya & 41. & Puttalama District & Cheliwe \\
\hline 17. & Dompe D.S. & Pugoda & 42. & Kurunegala District & Kurunegala \\
\hline 18. & Gampaha D.S. & Gampaha & 43. & Kegalle District & Kegalle \\
\hline 19. & Jaela D.S. & Ragama & 44. & Rathnapura District & Rathnapura \\
\hline 20. & Katana D.S. & Wattala & 45. & Southern Province & Matara \\
\hline 21. & Kelaniya D.S. & Kiribathgoda & 46. & Central Province & Kandy \\
\hline 22. & Mahara D.S. & Mahara & 47. & Uva Province & Badulla \\
\hline 23. & Minuwangoda D.S. & Minuwangoda & 48. & Eastern Province & Trincomalee \\
\hline 24. & Meerigama D.S. & Meerigama & 49. & North Central Province & Anuradapura \\
\hline 25. & Negombo D.S. & Negombo & 50. & Northern Province & Kilinochchi \\
\hline
\end{tabular}




\section{Desire Line Diagram For Weekend Arrivals to OUSL (Walk-in) From Western Province (8:00 -18:00)}

LEGEND

01- Colombo Divisional Secretariat

02- Dehiwala Divisional Secretariat

03. Homagama Divisional Secretariat

04 - Kaduwela Divisional Secretariat

05. Kesbewa Divisional Secretariat

06. Kolonnawa Divisional Secretariat

07 - Kotte Divisional Secretariat

08 - Maharagama Divisional Secretariat

09 - Moratuwa Divisional Secretariat

10. Padukka Divisional Secretariat

11. Ratmalana Divisional Secretariat

12. Seethawaka Divisional Secretariat

13. Thimbirigasyaya Divisional Secretaria

14 - Attanagalla Divisional Secretariat

15. Biyagama Divisional Secretariat

16. Divulapitiya Divisional Secretaria

17. Dompe Divisional Secretariat

18- Gampaha Divisional Secretariat

19. Ja-Ela Divisional Secretariat

20- Katana Divisional Secretariat

21. Kelaniya Divisional Secretariat

22. Mahara Divisional Secretariat

23. Minuwangoda Divisional Secretariat

24 - Mirigama Divisional Secretariat

25- Negombo Divisional Secretariat

26. Wattala Divisional Secretariat

27 - Agalawatta Divisional Secretariat

28. Bandaragama Divisional Secretariat

29 - Beruwala Divisional Secretariat

30. Bulathsinhala Divisional Secretaria

31. - Dodangoda Divisional Secretariat

32. Horana Divisional Secretariat

33. - Ingiriya Divisional Secretariat

34. Kalutara Divisional Secretariat

35- Madurawela Divisional Secretariat

36. Mathugama Divisional Secretariat

37. Millaniya Divisional Secretariat

38 - Palindanuwara Divisional Secretariat

39. - Panadura Divisional Secretariat

40. Walallavita Divisional Secretari

41. Puttalam District

42. Kurunegala Distric

43- Kegalle District

44 - Ratnapura District

45- Southern Province

46 - Central Province

47. Uva Province

49. North Central Province

50 - Northern Province
(50)

(41)

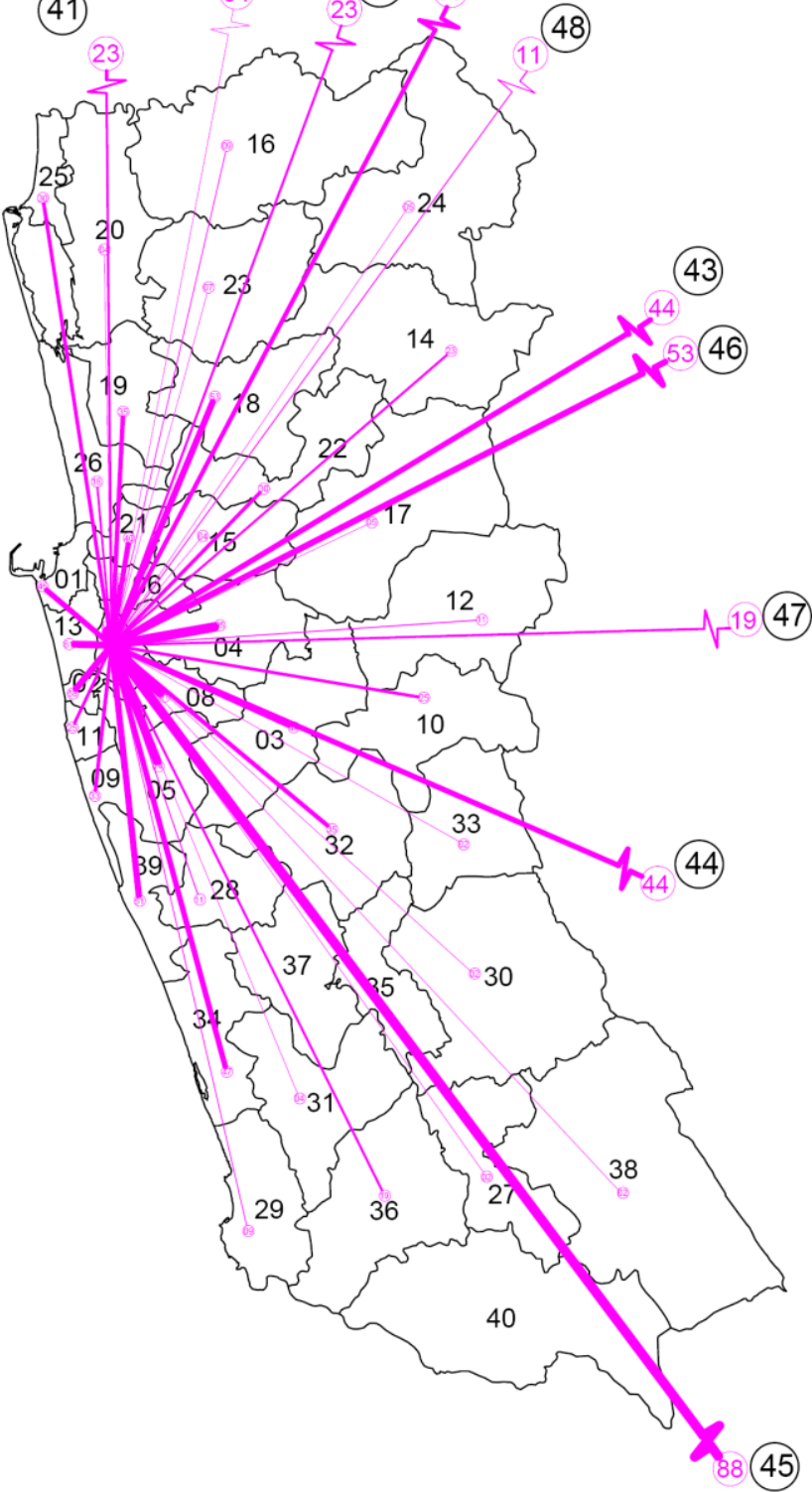

Figure 21. Picture of Desire Line Diagram for weekend walk-in 


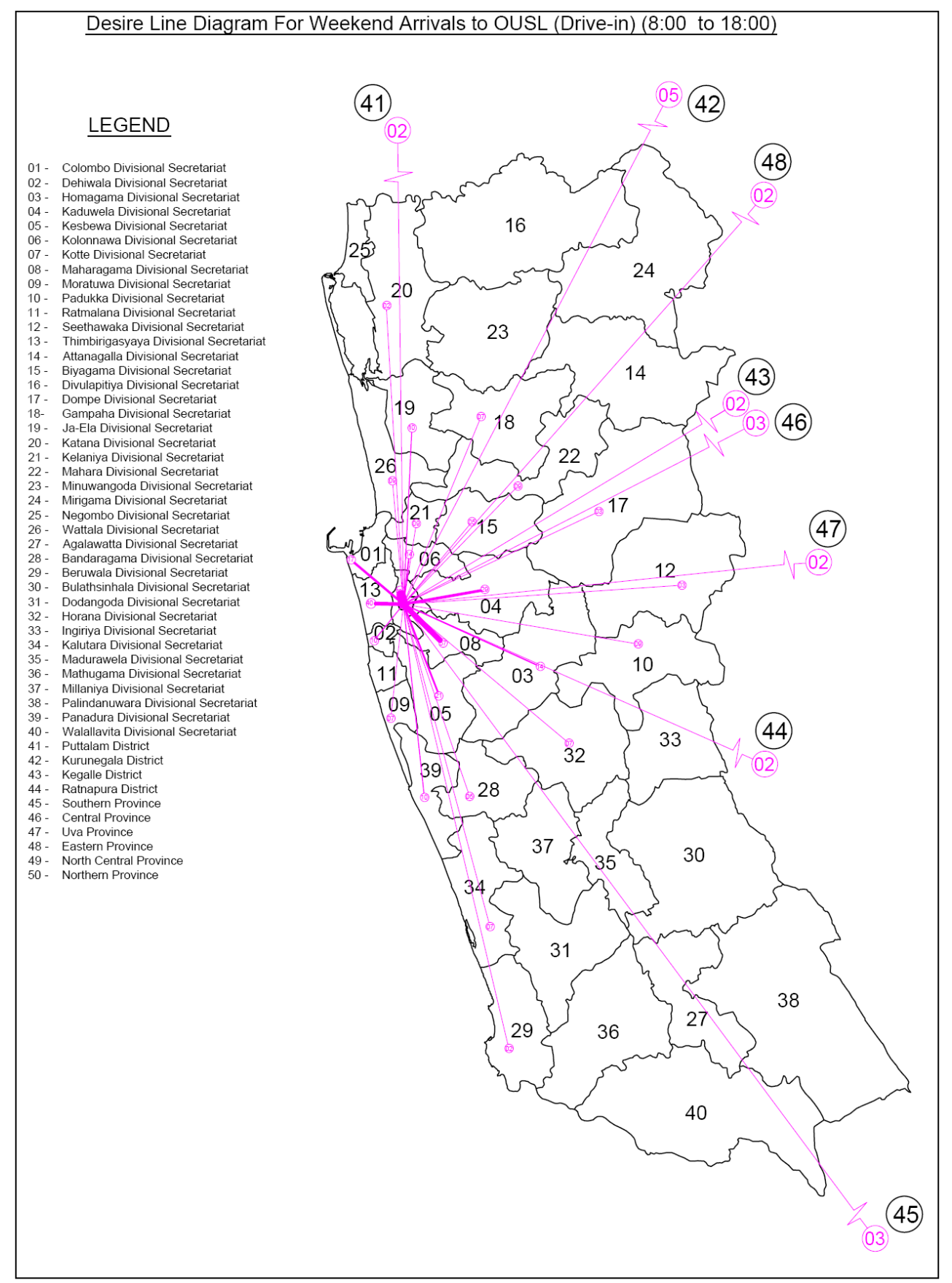

Figure 22: Picture of Desire Line Diagram for weekend drive-in 
Desire Line Diagram For Midweek Arrivals to OUSL (Walk-in) From Western Province (8:00 -18:00)

LEGEND

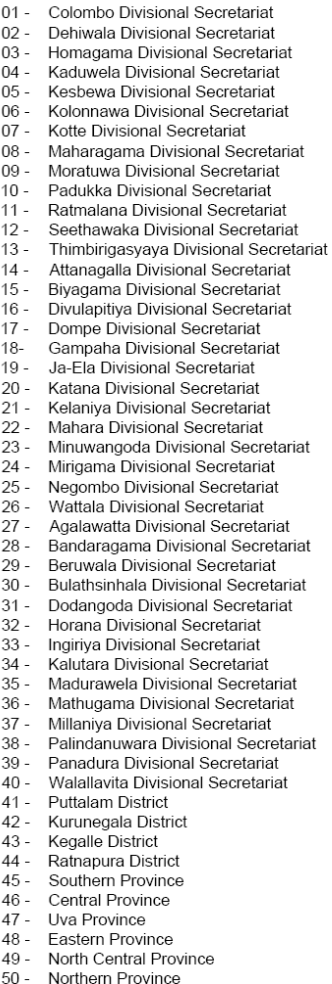

1 - Colombo Divisional Secretariat

Homagama Di

- Kaduwela Divisional Secretariat

Kesbewa Divional Secretariat

Kotte Divisional Secretariat

- Maharagama Divisional Secretariat

Moratuwa Divisional Secretariat

Padukka Divisional Secretariat

Thimbirigasyaya Divisional Secretariat

Attanagalla Divisional Secretariat

Javist

Katana Divisional Secretariat

Manara Divisional Secretariat

Minuwangoda Divisional Secretaria

Mirigama Divisional Secretariat

Negombo Divisional Secretariat

Agalawatta Divisional Secretariat

Bandaragama Divisional Secretariat

Beruwala Divisional Secretariat

Dot ninala Divisional Secretariat

Honn

Palindanuwara Divisional Secretaria

Panadura Divisional Secretariat

- Puttalam District

22 - Kurunegala District

- Ratnapura District

5 - Southern Provinc

- North Central Provin

50 - Northern Province

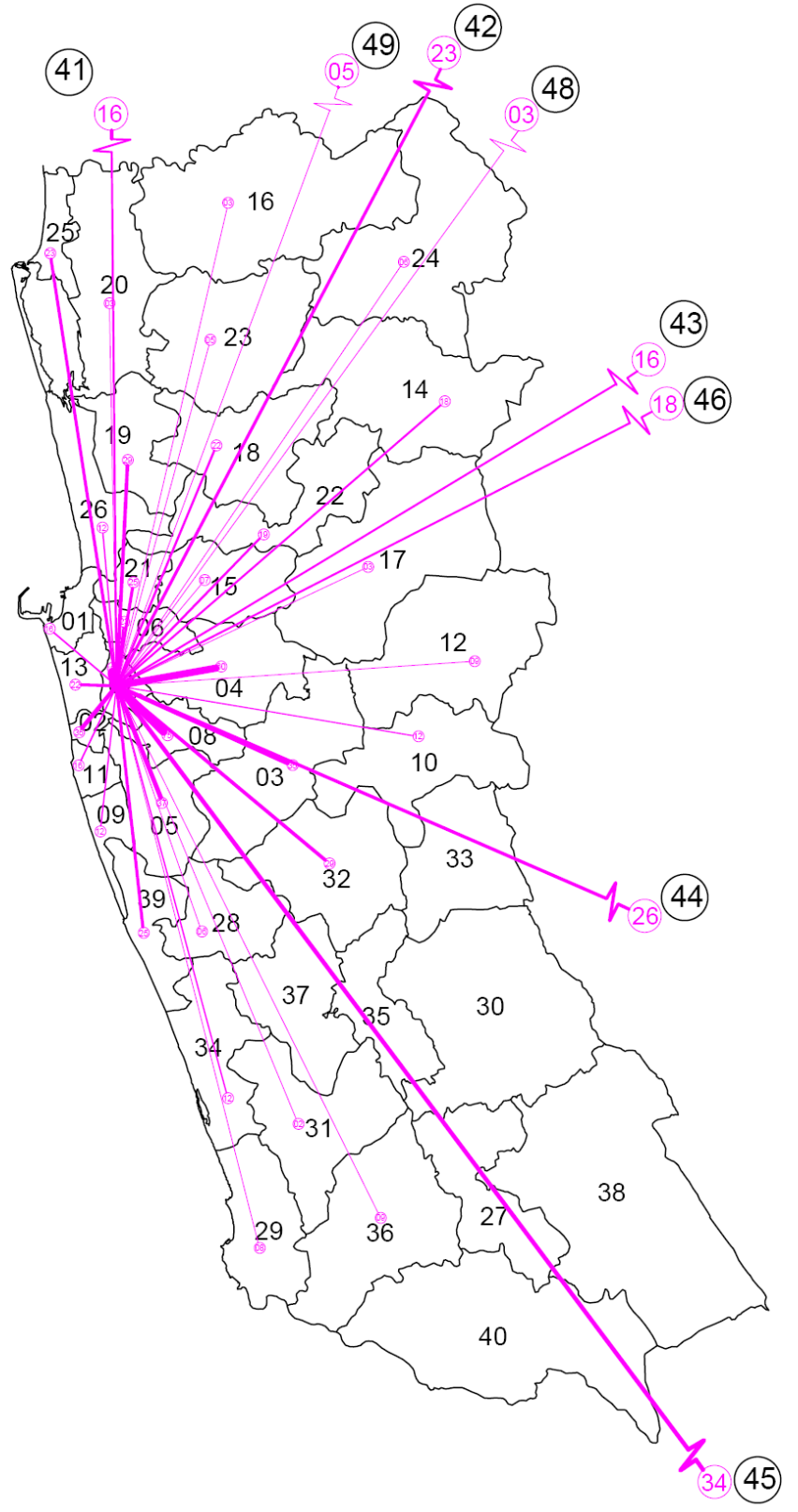

Figure 23: Picture of Desire Line Diagram for midweek walk-in 


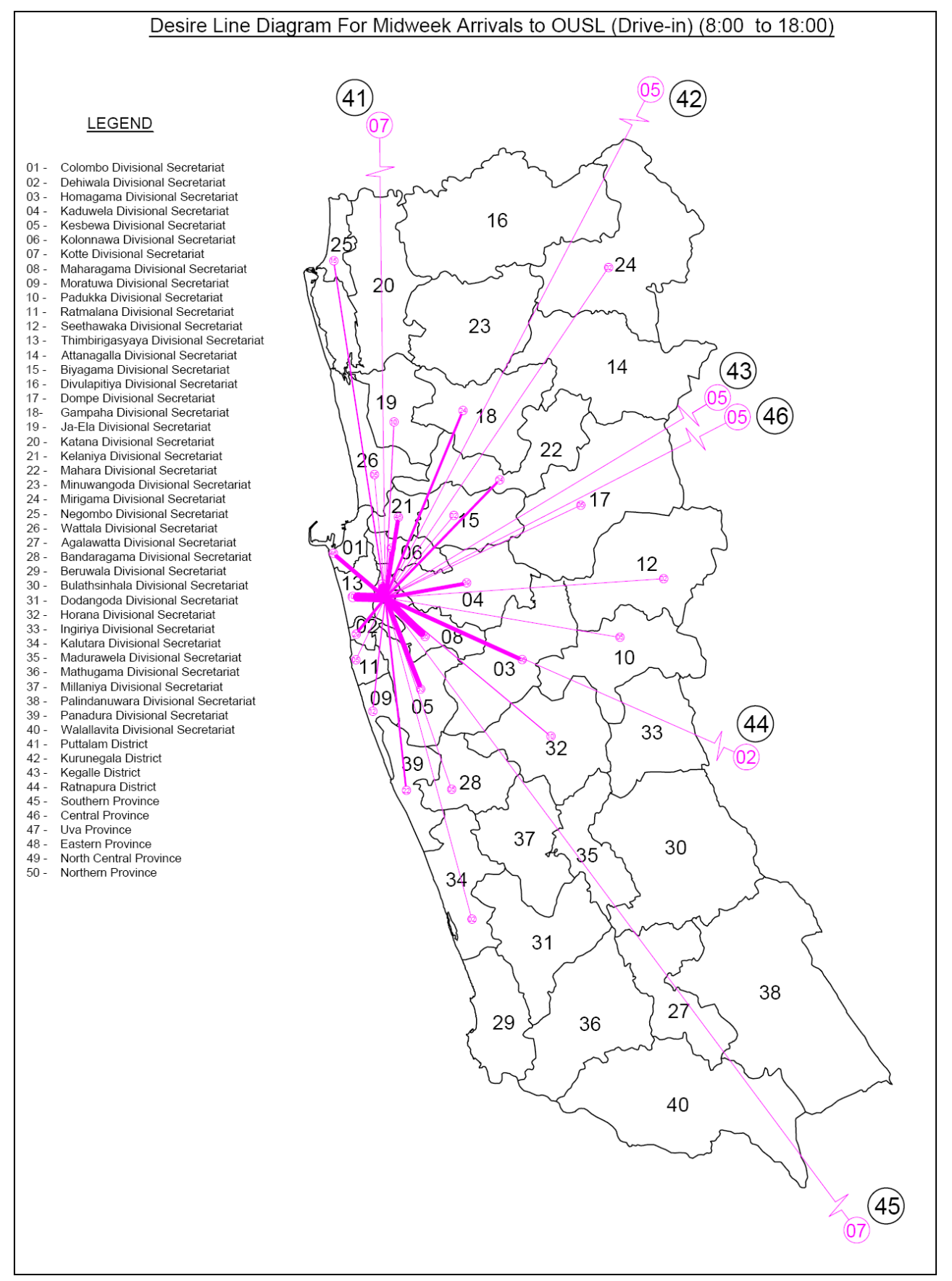

Figure 24: Picture of Desire Line Diagram for midweek drive-in 


\section{Proposed Shuttle Service}

By analyzing the data, it was identified that the peak inflow to the university occurs between 8:15 am - 9:15 am. Also there was a steady continuous inflow between 8:00 am - 10:00 am. To provide a better service for a considerable community it was decided to propose a bus shuttle service for 02 hours considering the distance and travel timing via a Google map. The starting point of the bus is to be the nucleus of each zone. The proposal is as follows:

Table 5. Weekend proposed shuttle service

\begin{tabular}{|c|c|c|c|c|c|c|c|c|}
\hline 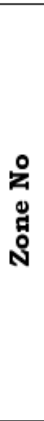 & ถั่ & 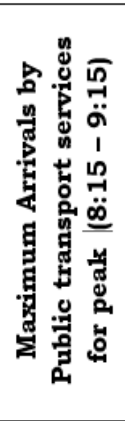 & 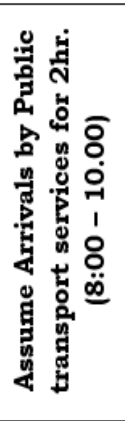 & 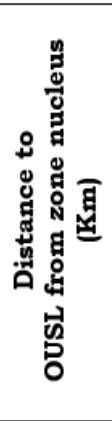 & 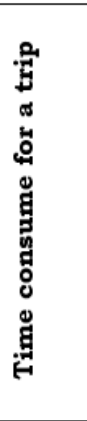 & 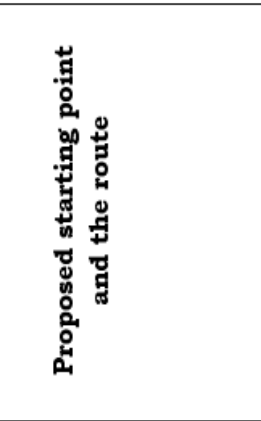 & 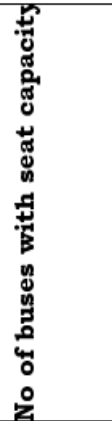 & 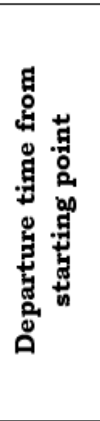 \\
\hline 07 & Kotte & 48 & 96 & 3.9 & $\begin{array}{l}10 \\
\min \end{array}$ & $\begin{array}{l}\text { Rajagiriya bus } \\
\text { stand to OUSL }\end{array}$ & $\begin{array}{l}26 \text { seats } \\
X \\
04 \text { nos. }\end{array}$ & $\begin{array}{l}8.00 \mathrm{am} \\
8.30 \mathrm{am} \\
9.00 \mathrm{am} \\
9.30 \mathrm{am}\end{array}$ \\
\hline 04 & Kaduwela & 42 & 84 & 12.8 & $\begin{array}{l}35 \\
\min \end{array}$ & $\begin{array}{l}\text { Malabe bus stand } \\
\text { through } \\
\text { Kaduwela, } \\
\text { Rajagiriya to OUSL }\end{array}$ & $\begin{array}{l}26 \text { seats } \\
\quad X \\
04 \text { nos. }\end{array}$ & $\begin{array}{l}7.30 \mathrm{am} \\
8.00 \mathrm{am} \\
8.30 \mathrm{am} \\
9.00 \mathrm{am}\end{array}$ \\
\hline 08 & Maharagama & 37 & 74 & 6.6 & $\begin{array}{l}25 \\
\min \end{array}$ & $\begin{array}{l}\text { Maharagama bus } \\
\text { stand through } \\
\text { Nugegoda to OUSL }\end{array}$ & $\begin{array}{l}26 \text { seats } \\
X \\
03 \text { nos. }\end{array}$ & $\begin{array}{l}8.00 \mathrm{am} \\
8.30 \mathrm{am} \\
9.00 \mathrm{am}\end{array}$ \\
\hline 45 & $\begin{array}{l}\text { Southern } \\
\text { Province }\end{array}$ & 37 & 74 & $11^{*}$ & $\begin{array}{l}40 \\
\min ^{*}\end{array}$ & $\begin{array}{l}\text { Kottawa bus stand } \\
\text { through } \\
\text { Maharagama, } \\
\text { Nugegoda to OUSL }\end{array}$ & $\begin{array}{l}26 \text { seats } \\
\quad X \\
03 \text { nos. }\end{array}$ & $\begin{array}{l}7.45 \mathrm{am} \\
8.15 \mathrm{am} \\
8.45 \mathrm{am}\end{array}$ \\
\hline 05 & Kesbewa & 30 & 60 & 11.7 & $\begin{array}{l}25 \\
\min \end{array}$ & $\begin{array}{l}\text { Pilixandala bus } \\
\text { stand through } \\
\text { Nugegoda to OUSL }\end{array}$ & $\begin{array}{l}26 \text { seats } \\
\quad X \\
02 \text { nos. }\end{array}$ & $\begin{array}{l}8.00 \mathrm{am} \\
8.45 \mathrm{am}\end{array}$ \\
\hline 18 & Gampaha & 27 & 54 & 32.3 & $\begin{array}{l}01 \mathrm{hr} \\
05 \\
\min \end{array}$ & $\begin{array}{l}\text { Gampaha bus } \\
\text { stand through } \\
\text { Kadawatha } \\
\text { Rajagiriya to OUSL }\end{array}$ & $\begin{array}{l}26 \text { seats } \\
\quad X \\
02 \text { nos. }\end{array}$ & $\begin{array}{l}7.15 \mathrm{am} \\
8.15 \mathrm{am}\end{array}$ \\
\hline 02 & Dehiwala & 27 & 54 & 5.8 & $\begin{array}{l}25 \\
\min \end{array}$ & $\begin{array}{l}\text { Dehiwala bus stand } \\
\text { through Kohuwala, } \\
\text { Nugegoda to OUSL }\end{array}$ & $\begin{array}{l}26 \text { seats } \\
\quad X \\
02 \text { nos. }\end{array}$ & $\begin{array}{l}7.45 \mathrm{am} \\
8.30 \mathrm{am}\end{array}$ \\
\hline
\end{tabular}


Table 6. Midweek proposed shuttle service

\begin{tabular}{|l|l|l|l|l|l|l|l|l|}
\hline & & & & & \\
\\
\end{tabular}

* The OUSL users who come from the Southern Province use various modes of travel. But we assume that most of them use the southern expressway. Also since there is a multi-model transport center that is constructed in Kottawa by the Colombo Mega-polis program we decided to collect those people from Kottawa bus stop.

According to Table 5, the required number of buses is 20 (26-seater 
capacity) during the weekends. Also, according to Table 6 , the required number of buses is 04 (52-seater capacity) and 16 (26-seater capacity) during midweek.

\section{Conclusions}

The intention of this study was to analyse the arrival pattern of commuters to OUSL's Colombo Regional Center and the main university in Nawala with their travel origins and their travel mode patterns. Also, it looked at the factors with the intention of improving the traveling facilities for OUSL users by minimizing the travel time and studying their travel mode. At the beginning of this study, it hoped to propose a shuttle service for users who use buses and propose a suitable schedule for trains for the users who use trains during peak travel times. The survey was conducted over two days, one during mid-week and the other during the weekend. During the survey, walkers and motorists coming to OUSL through all four gates were interviewed and this process saw the research team contacting more than 1,000 respondents. The survey captured about $58 \%$ of total arrivals during the weekend and $56 \%$ during a mid-weekday.

During the weekend, most of the walkers came through gate 01 , of the 1,000 arrivals and more than 600 were interviewed. Most of the weekend motorists came through gate 03, of the 200 more than 125 were interviewed. During midweek most of the walkers came in through gate 01 , of the 850 more than 550 were interviewed. Most of the motorists during midweek and weekend came through gate 03, of the 500 and more than 200 were interviewed.

Correlated to the objectives of study, Sri Lanka was divided in to 50 zones with identified nucleus points. Expansion factor was used to obtain the actual vales of arrival via the individual zone. Accordingly, during the weekend most of the walkers to OUSL came from Kotte DSD (158). Also, most of the motorists came from Kotte DSD (98). During midweek, most of the walkers (176) and most of the motorist (174) came from Kotte DSD. Those flows of arrivals from zone to OUSL are illustrated on maps using desire lines.

Shuttle Services are designed to provide a better service for OUSL users during the peak arrival time (8:00 am to 10:00 pm). During the weekend, it is proposed to start shuttle services from Kotte, Kaduwela, 
Maharagama, Kottawa, Kesbewa, Gampaha and Dehiwala. During the midweek, shuttle services are proposed from Kotte, Maharagama, Kaduwela, Kottawa, Kesbewa, Gampaha, Horana and Thibirigasyaya.

\section{Weekend arrivals}

During the weekend most visitors to the university (more than 52\%) come through Nugegoda. Most visitors come from zone no 7 (Kotte DS Division). The community who came to the university for study purposes is $82 \%$ while for work $13 \%$, and for other purposes $5 \% .48 \%$ of those are females; $52 \%$ of males came to the university during the weekend. More than $69 \%$ use public transport services, while more than $27 \%$ private transport and $4 \%$ walked. From those public transport users, more than $74 \%$ came to OUSL by bus and more than $10 \%$ by train. Majority of motorists used the motor cycle $(49 \%)$ while the others used private transport services (35\%) and three-wheeler (10\%). When considering the peak time arrivals, $89 \%$ of them directly come to OUSL for academic purposes while the others came for other business.

\section{Midweek arrivals}

During midweek the most of the university community (more than 51\%) come through Nugegoda. Most visitors came from zone no 7 Kotte Divisional Secretary. The community who came for study purposes is 60 $\%$; those who came to work is $30 \%$; for other purposes is $10 \% .46 \%$ of them are females; 54\% males came during midweek. More than 55\% use public transport services, more than $39 \%$ private transport and $6 \%$ walked. From those public transport users more than $74 \%$ came to OUSL by bus and more than $9 \%$ by train. Majority of motorists used private transport servicea (40\%) while others used motor cycles $(38 \%)$ and three-wheeler (13\%). When considering the peak time arrivals $93 \%$ came for academic purposes while the others came for other business.

\section{References}

Hollander, Y. (2016), Transport Modelling for a Complete Beginner, CTthink, London.

https://en.wikipedia.org

https://nptel.ac.in

http: / www.maps.google.lk

http://www.moha.gov.lk

http://www.ou.ac.lk 
http: / /www.slideshare.com

https://www.survey.gov.lk

Kanna, S. K. and Justo, C. E. G. (2011), Highway Engineering, Nem Chand \& Bros., India.

Manikantaswamy V. S. (2005), Origin and destination survey, University of Mysore, Manasagangothri. http:/ /www.slideshare.com.

Patel, A. N. (2006), Traffic Studies, http://www.slideshare.com.

Vandebona, U., Weerasekera, K. and Kim, K. S. (1997), KUR-RIN-GAI Campus Origin Distribution Survey - 1997 Update, Department of Transport Engineering, University of New South Wales, Sydney.

Vandebona, U., Weerasekera, K. and Upadhyay, P.K. (1994), KUR-RINGAI Campus Origin Pattern Survey, Department of Transport Engineering, University of New South Wales, Sydney

Zuylen, J. V. and Willumsen, G. (1980), The Most Likely Trip Matrix Estimated from Traffic Counts, University of Leeds, Leeds. 